Н.А. Галушко

Сумський державний університет

\title{
Закономірності розвитку епідемічного процесу вірусного гепатиту C в Сумській області
}

Робота присвячена вивченню закономірностей розвиткуепідемічного процесу вірусного гепатиту С (ВГС) в Сумській області у період 1991-2019рр. У дослідженні застосовано комплекс описово-оціночних та аналітичних прийомів епідеміологічного методу дослідження в поєднанні з методами математичної статистики. Встановлено динаміку, інтенсивність епідемічного процесу ВГС, провідні шляхи передачі збудника, а також території та групи підвищеного ризику. Зроблена спроба оцінити масштаби латентного епідемічного процесу ВГС на території Сумської області, а також пояснити причини наявних тенденцій захворюваності на гострий $і$ хронічний ВГС. Встановлено такі епідеміологічні риси ВГС на території Сумської області в період 1991-2019 рр.: 25-кратне зростання показників захворюваності на тлі зниження активності механізму передачі інфекції, помірний спад гострого ВГС і водночас помірне зростання хронічної форми інфекції, 35-кратне зменшення масштабів латентного епідемічного процесу, дворазове переважання захворюваності чоловіків над захворюваністю жінок, істотне зниження хронічного і помірне - гострого ВГС серед дітей, низька ефективність епідеміологічних розслідувань випадків ВГС та істотна нерівномірність територіального розподілу випадків цієї інфекції.

Ключові слова: вірусний гепатит $C$, епідемічний процес, шляхи передачі, групи ризику.

\section{Вступ}

Згідно з даними Всесвітньої організації охорони здоров'я, не менше 71 млн (1\%) населення світу інфіковано вірусом гепатиту C (HCV-інфекція). Кількість нових випадків у світі перевищуе 3 млн на рік, ще близько 350 тис. хворих на вірусний гепатит С (ВГС) щороку вмирають від його ускладнень (World Health Organization, 2017). За оцінками експертів, соціально-економічний тягар ВГС дуже значний. Наприклад у США, де інфіковано близько 1,6\% населення, він перевищує 10 млрд дол. на рік (Stepanova M., Younossi Z.M., 2017). У 2016 р. Всесвітня організація охорони здоров'я опублікувала основні положення глобальної стратегії протидії вірусним гепатитам, у тому числі ВГС. Мета цієї стратегії - ліквідація вірусного гепатиту як основної загрози для громадського здоров'я, до 2030 р. (World Health Organization, 2016).

У Сумській області, яка посідає провідне місце у регіональній структурі захворюваності на ВГС в Україні, розроблена та впроваджена Програма діагностики, лікування та профілактики вірусних гепатитів на період до 2023 р. Концепція подолання проблеми ВГС в області включає три напрямки:

1. Забезпечення якісної діагностики і виявлення хворих на ранній стадії захворювання.

2. Забезпечення доступності сучасного лікування ВГС.

3. Проведення інформаційно-освітніх заходів.

Мета роботи - вивчення закономірностей розвитку епідемічного процесу ВГС у Сумській області, що дозволить деталізувати програмні заходи боротьби з цією інфекцією в регіоні.

\section{Об'єкт і методи дослідження}

Для аналізу епідеміологічної ситуації щодо ВГС використані дані річних звітів ДУ «Сумський обласний лабораторний центр МОЗ України», КЗ “Сумський обласний інформаційно-аналітичний центр медичної статистики» за період 2010-2019 рр.

У дослідженні застосовано комплекс описово-оціночних та аналітичних прийомів епідеміологічного методудослідження у поєднанні з методами математичної статистики. Кількісні виміри змін у ході епідемічного процесу оцінювали за показником середнього темпу приросту або зниження захворюваності ( $\left.\mathrm{T}_{\text {сер. }}\right)$. Для визначення зв'язку між явищами розраховували лінійний коефіцієнт кореляції та його середньоквадратичну похибку $\left(r, m_{r}\right)$. Силу кореляційного зв'язку оцінювали за шкалою Чеддока. Значущість лінійного коефіцієнта кореляції визначали за допомогою розрахункового критерію Стьюдента $\left(\mathrm{t}_{\text {розр. }}\right)$ з подальшим зіставленням з його критичним значенням $\left(t_{\text {крит. }}\right)$. Якщо $t_{\text {розр. }}$ перевищувало $t_{\text {крит. }}$, то лінійний коефіцієнт кореляції вважали значущим, а зв'язок між змінними величинами - суттєвим, і навпаки: достовірність оцінювали за таблицею стандартних коефіцієнтів кореляції на рівні безпомилкового прогнозу $\geqslant 95 \%(p \leqslant 0,05)$. Достовірність різниці відсоткових показників визначали за величиною їх середньої похибки. 3 врахуванням відносних величин, що порівнювалися, та ї середніх похибок розраховували довірчий коефіцієнт $\mathrm{t}_{\mathrm{p}}$. Ранжування територій проводили шляхом розподілу варіаційного ряду на квартилі. Для статистичної обробки інформації використовували програмний пакет «Microsoft Office Excel 2010».

\section{Результати та їх обговорення}

у 1990-х рр. діагностику ВГС на території Сумської області проводили виключно у рамках наукових досліджень. Маркери вірусу виявляли у реакції імуноферментного аналізу з використанням комерційних тест-систем 1-го і 2-го поколінь; позитивні результати підтверджували у реакції нейтралізації. За даними цих досліджень інтенсивні показники захворюваності на ВГС у 19911992 рр. становили 1,3-1,4 на 100 тис. населення (Трецкая Т.А., 1993). У 2003-2007 рр., на початку офіційної реєстрації гострих форм ВГС, захворюваність дещо зросла до рівня 1,9-2,15 на 100 тис. населення. Починаючи з 2009 р., захворюваність на ВГС в області зростала інтенсивніше, що збіглося з упровадженням офіційної реєстрації хронічних форм цієї інфекції. У 2019 р. загальна захворюваність на ВГС в Сумській області перевищувала рівень 1991 р. у 25 разів. При цьому динамічні зміни захворюваності на гострий і хронічний ВГС мали протилежні тенденції: на тлі помірного зниження захворюваності на гострий ВГС із темпом 3,2\% показники хронічного ВГС у Сумській області, навпаки, зростали з темпом 2,6\% (рис. 1). Співвідношення гострих і хронічних форм ВГС в Сумській області у період 20102019 рр. становило в середньому 1:24. Загалом по Україні цей показник дорівнював 1:10, у країнах Європейського Союзу $(€ C)-$ $1: 48$.

Зміна перебігу ВГС у напрямку зменшення кількості гострих та збільшення хронічних випадків має певні епідеміологічні передумови. Вважають, що клінічно яскраві випадки ВГС виникають, якщо в організм потрапляє значна кількість збудника, що найчастіше відбувається при артифіціальному шляху зараження (Шагинян В.Р. и соавт., 2012). Це підтверджується даними епідеміологічних спостережень. Так, у період 2010-2013 рр. у США зареєстроване різке, майже трикратне, підвищення захворюва- 


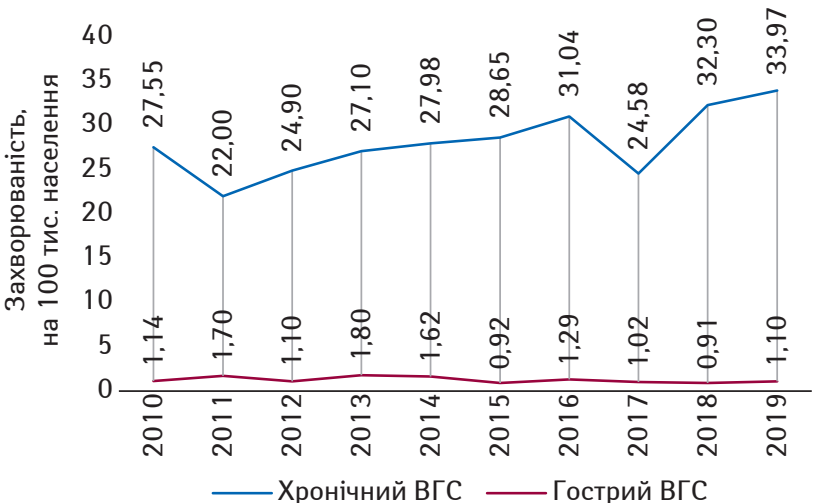

Рис. 1. Захворюваність на гострий та хронічний ВГС у Сумській області в період 2010-2019 рр.

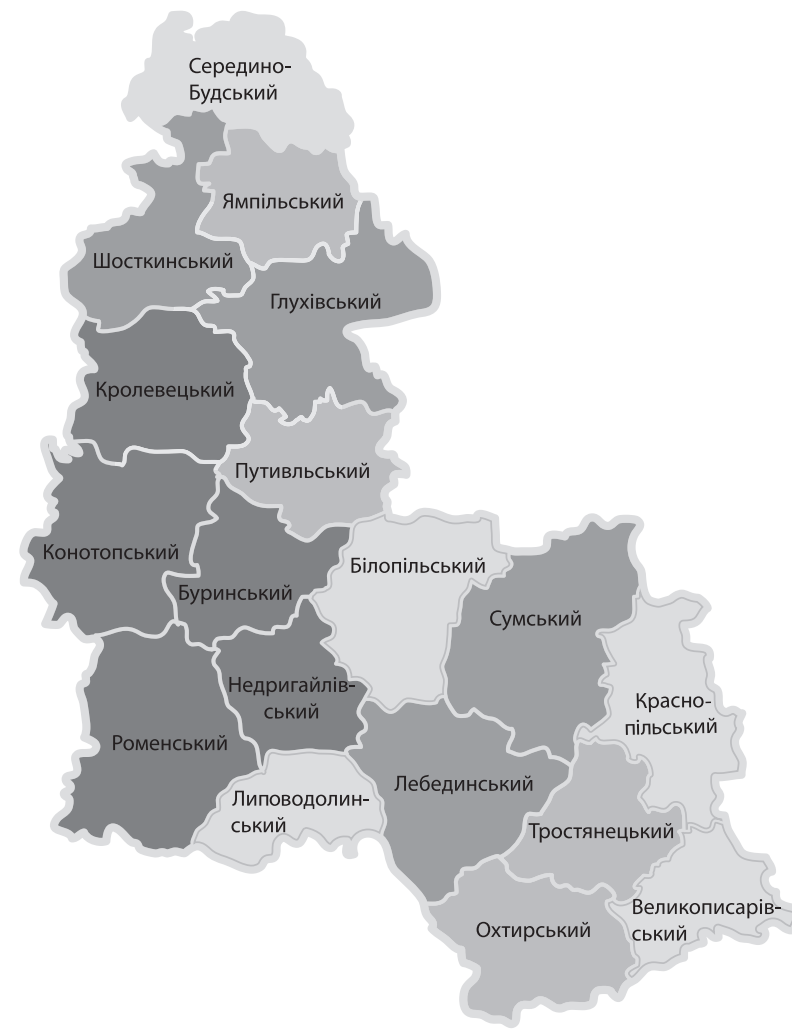

Рис. 2. Поширеність HCV-інфекції в районах Сумської області (інтенсивність забарвлення територій на карті відповідає квартилям та зростає від нижнього до верхнього квартиля)

ності на гострий ВГС після тривалого спаду захворюваності, що було пов'язане з ростом споживання населенням наркотичних засобів (Lingala S., 2015). Збільшення значущості природних шляхів передачі вірусу закономірно відображається у збільшенні стертих форм інфекції, які виявляються лише за умов широкого охоплення населення діагностикою. У зв'язку з цими уявленнями, тенденція щодо помірного зниження захворюваності на гострий ВГС у Сумській області свідчить про деяке зменшення ролі штучних шляхів передачі збудника. Ситуація щодо підвищення захворюваності на хронічний ВГС у області пов'язана зі збільшенням охоплення населення діагностикою цієї інфекції.

При ранжуванні показників поширеності ВГС на різних територіях Сумської області до верхнього квартиля з середнім показником 335,8 на 100 тис. населення віднесені Конотопський, Роменський, Недригайлівський та Буринський райони, у нижній квартиль з показником 89,43 на 100 тис. населення потрапили Краснопільський, Великописарівський, Білопільський, Липоводолинський і Серединобудський райони. Майже 4-кратна відмінність показників поширеності ВГС у верхньому та нижньому квартилях відображає суттєві відмінності в активності механізму передачі вірусу на цих територіях. Зазначимо, що райони верхнього квартиля з найвищим поширенням ВГС є географічно суміжними (рис. 2), що вірогідно зумовлено наявністю схожих і, можливо, спільних умов, що підтримують активність механізму передачі інфекції на цих територіях.

Захворюваність на ВГС дитячого населення Сумської області у період 2010-2019 рр. була у 6-30 разів нижчою, ніж серед дорослих. Середньобагаторічний показник захворюваності на ВГС дітей протягом 2010-2019 рр. становив 1,63 на 100 тис. із коливанням в окремі роки від 4,3 на 100 тис. до 0. Динамічні зміни захворюваності на ВГС дитячого населення області характеризуються вираженою тенденцією до зниження частоти хронічних форм ( $\left.\mathrm{T}_{\text {сер }}=-17 \%\right)$ та помірним зниженням частоти ВГС з гострим перебігом ( $\left.T_{\text {сер. }}=-1,6 \%\right)$. Встановлено помірний зворотний кореляційний зв' язок між захворюваністю на хронічний ВГС дорослих та дітей; $r=-0,664 \pm 0,19\left(t_{\text {розо. }}=3,5\right)$.

Віковий аналіз захворюваності свідчить, що ВГС найчастіше реєструють у віковій групі 25-49 років із середньою захворюваністю 47,46 на 100 тис. населення, що удвічі більше, ніж у вікових групах 15-24 роки (22,64 на 100 тис. населення) та $>50$ років $(22,54$ на 100 тис. населення). Зазначимо, що на вірусний гепатит В (ВГВ) частіше хворіють особи віком 15-24 роки (17,92 на 100 тис. населення) і найрідше ->50 років (6,83 на 100 тис. населення).

У період 1991-1993 рр. віковий розподіл захворюваності на ВГС у Сумській області був іншим - частота виявлення маркерів вірусу підвищувалась з віком і становила 2,05\% серед осіб віком $15-29,3,65 \%-30-49$ та $6,15 \%->50$ років. Аналогічну тенденцію до збільшення з віком частоти інфікування простежували і для ВГВ.

У Сумській області чоловіки хворіють на ВГС у 2 рази частіше ніж жінки. Цей гендерний диспаритет серед дорослих хворих на ВГС зберігається також загалом по Україні, хоча і меншою мірою $(1,29: 1)$. Дані моніторингу в інших країнах також свідчать про вищу поширеність ВГС серед чоловіків. У США це співвідношення становить 1,4:1 (CDC United States, 2013), в Канаді - 1,31:1 (Wu H.X. et al., 2006), у країнах ЄC - 2:1 (ECDC EU, 2017). При цьому передачу вірусу ВГС, як і ВІЛ, шляхом незахищеного статевого контакту від чоловіка до жінки вважають більш імовірною, ніж від жінки до чоловіка (Evans J.L. et al. , 2003). Однак після інфікування ужінок частіше ніж у чоловіків відбувається спонтанне звільнення від вірусу, а у разі розвитку хронічного ВГС патологічні зміни в печінці прогресують повільніше ніж в осіб чоловічої статі, що пояснюють захисним ефектом естрогенів (Baden R. et al., 2014). Свій внесок у статевий дисбаланс вносять різні соціогромадські та поведінкові нашаровування, наприклад більша схильність чоловіків до ризикового способу життя, що підтверджується даними епідеміологічних спостережень. Так, у Сумській області серед осіб, що інфікувалися ВГС та ВГВ під час вживання ін'єкційних наркотиків, чоловіків майже у 9 разів більше ніж жінок.

Для визначення активності тих чи інших шляхів передачі ВГС проведено порівняння частоти інфікування у групах підвищеного ризику. Встановлено, що у період 1991-1993 рр. поширеність ВГС серед осіб високого ризику суттєво перевищувала таку у загальній популяції: у 1,6 раза серед медичних працівників, у 1,9-серед хворих гематологічних відділень, у 2,9 - серед осіб із венеричними хворобами та у 6,7 - серед споживачів ін'єкційних наркотиків (СІH) (табл. 1), що віддзеркалює суттєву роль останніх у поширенні ВГС у цей період. У цей самий період поширеність ВГВ угрупах ризику була приблизно однаковою і менш вираженою порівняно з усім населенням області (лише у 2,3 раза).

у 2017 р., порівняно з 1991 р., кількість інфікованих на ВГС

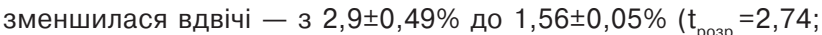
$\mathrm{p}<0,05)$, а кількість інфікованих на ВГВ - майже у 4 рази: $32,6 \pm 1,41$ до 0,66 0,03\% (p<0,05) (див. табл. 1). Поширеність HCV-інфекції серед пацієнтів наркологічних диспансерів знизилася втричі

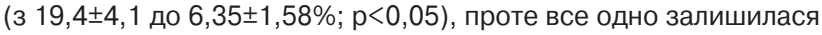
найвищою серед усіх верств населення, що не є дивним, оскільки кількість СІН в області за останні 13 років збільшилася на 25\%, а інтенсивний показник зріс з 63,4 до 81,5 на 100 тис. населення у 2003 та 2016 рр. відповідно. До того ж, тільки 45\% СІН із синдромом залежності від опіоїдів охоплені замісною підтримувальною терапією (Державна установа «Український моніторинговий 
та медичний центр з наркотиків та алкоголю Міністерства охорони здоров'я України», 2017).

Значний рівень поширеності HCV-інфекції у 2017 р. спостерігали також серед хворих, які протягом тривалого часу перебува-

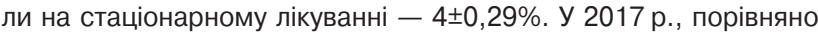
із 1991 р., поширеність HCV-інфекції серед осіб із венеричними хворобами зменшилася майже у 4 рази $(8,3 \pm 4,0$ та $2,15 \pm 0,05 \%$ відповідно; p<0,05). Найбільшою мірою циркуляція вірусу скоротилася серед медичних працівників - у 4,8 раза $(4,8 \pm 1,8$ та $1,0 \pm 0,14 \%$ відповідно; $p<0,05)$. Зазначено, що спад епідемічного процесу HBV-інфекції після 1991 р. відбувався більш інтенсивно: частота виявлення HBsAg серед всієї популяції знизилася у 4 у групі медичних працівників - у 12,6, серед осіб із венеричними хворобами - у 13,4 раза. При цьому циркуляція вірусу гепатиту $B$, як і вірусу гепатиту C, серед СІН зменшилася лише у 3 рази.

Таблиця 1. Поширеність маркерів (\%) HCV-інфекції (анти-HCV) та HBVінфекції (HBsAg) серед населення груп ризику у Сумській області у 1991 та 2017 p.

\begin{tabular}{|c|c|c|c|c|}
\hline \multirow{2}{*}{ Група населення } & \multicolumn{2}{|c|}{ HCV-інфекція } & \multicolumn{2}{|c|}{ HBV-інфекція } \\
\hline & 1991 p. & 2017 p. & 1991 p. & 2017 p. \\
\hline Медичні працівники & $4,8 \pm 1,8$ & $1,0 \pm 0,14$ & $4,9 \pm 1,8$ & $0,39 \pm 0,09$ \\
\hline $\begin{array}{l}\text { Хворі наркологічних } \\
\text { диспансерів }\end{array}$ & $19,4 \pm 4,1$ & $6,35 \pm 1,58$ & $4,5 \pm 1,28$ & $1,37 \pm 0,79$ \\
\hline $\begin{array}{l}\text { Особи з венеричними } \\
\text { хворобами }\end{array}$ & $8,3 \pm 4,0$ & $2,15 \pm 0,05$ & $5,9 \pm 2,9$ & $0,44 \pm 0,44$ \\
\hline Хворі стаціонарних відділень & - & $4,0 \pm 0,29$ & - & $2,2 \pm 0,22$ \\
\hline $\begin{array}{l}\text { Хворі гематологічного } \\
\text { відділення }\end{array}$ & $5,5 \pm 2,4$ & - & $5,2 \pm 2,6$ & - \\
\hline Усе населення області & $2,9 \pm 0,49$ & $1,56 \pm 0,05$ & $2,6 \pm 1,41$ & $0,66 \pm 0,03$ \\
\hline
\end{tabular}

У період 2013-2019рр. частота виявлення інфікованих вірусом гепатиту C осіб серед індикаторних груп населення - донорів і вагітних характеризувалася стабільністю у динаміці ( $\mathrm{T}_{\text {. }}+0,58$ та -0,072 відповідно), становила в середньому 0,4 і 0,46\% відповідно і була утричі нижчою, ніж у загальній популяції, що можна пояснити тим, що зазначені категорії не охоплюють ті верстви населення, які найбільшою мірою залучені до епідемічного процесу.

Виявлення інфікованих вірусом гепатиту C осіб серед так званого здорового населення є об'єктивним індикатором прихованого епідемічного процесу. у 1991 р. на 1 випадок ВГС а також ВГВ, що мали маніфестний перебіг, припадало близько 2 тис. випадків безсимптомної інфекції (Трецкая Т.А., 1993). у 2017 р. це співвідношення зменшилося до 1:60 та 1:82 відповідно (табл. 2).

Загальна кількість інфікованого вірусом гепатиту С населення у 2017 р. зменшилася порівняно з 1991 р. у 1,87 раза. Для ВГВ це зменшення виявилося більш суттєвим - у 26,56 раза.

Таблиця 2. Частота реєстрації маніфестних та латентних форм HCV- та HBV-інфекції в Сумській області у 1991 та 2017 р.

\begin{tabular}{lcccc}
\hline \multicolumn{1}{c}{ Показник } & \multicolumn{2}{c}{ HCV-інфекція } & \multicolumn{2}{c}{ HBV-інфекція } \\
\cline { 2 - 5 } & $\mathbf{1 9 9 1}$ p. & $\mathbf{2 0 1 7}$ р. & $\mathbf{1 9 9 1}$ p. & $\mathbf{2 0 1 7}$ p. \\
\hline Маніфестні форми, \% & 0,0014 & 0,0256 & 0,0094 & 0,008 \\
Латентні форми, \% & 2,9 & 1,53 & 17,52 & 0,652 \\
Загальна кількість інфікованих, \% & 2,9014 & 1,5556 & 17,5294 & 0,66 \\
Співвідношення маніфестних та латент- & $1: 2071$ & $1: 60$ & $1: 1864$ & $1: 82$ \\
них форм інфекції & & &
\end{tabular}

У вітчизняних наукових джерелах виявлені лише поодинокі повідомлення про масштаби прихованого компонента епідемічного процесу вірусних гепатитів. Так, за даними В.Р. Шагінян (2007), співвідношення маніфестних та безсимптомних форм ВГВ в Україні у 2005 р. становило 1:120 середдорослих та 1:1000 середдітей.

Ефективність епідеміологічного розслідування випадків ВГС в області, як і в Україні в цілому, досить низька: шляхи інфікування встановлюють у 16-22\% випадків із тенденцією до зниження. у країнах ЄС шляхи інфікування встановлюють дещо частіше в середньому у $26 \%$ випадків ВГC (Wu H.X. et al., 2006) з деякими варіаціями у різних країнах. Так, в Ірландії, де рівень розповсюдження опіоманії становить >600 випадків на 100 тис. населення, фактори ризику встановлюють у 93\% зареєстрованих випадків ВГС, серед яких у не менше 80\% випадків інфікування відбувається внаслідок вживання ін'єкційних наркотиків (Crowley D. et al., 2019). Отже, у 13\% випадків інфікування ВГС у цієї країні встановлюють інші шляхи передачі збудника, не пов'язані зі вживанням ін'єкційних наркотиків, і ця частка наближається до українського показника. 3 урахуванням цих даних можна припустити, що шлях передачі вірусу гепатиту C при вживанні ін'єкційних наркотиків навряд чи є домінуючим в Україні та Сумській області зокрема. Проте у структурі встановлених шляхів передачі ВГС все ж таки переважає саме цей шлях: частка випадків інфікування внаслідок вживання ін'єкційних наркотиків становить 37\%. Частка випадків ВГС, пов'язаних із незахищеними статевими контактами, дещо менша - 33\%. Більше 4\% випадків ВГС із встановленим шляхом передачі пов'язані з проведенням лікувально-діагностичних процедур, у 25\% випадків мало місце переливання крові протягом інкубаційного періоду. У 2016 р. на 1 випадок ВГС в області припадало 4 938, а у 2017 р. - 28570 гемотрансфузій.

Роль донорів крові у поширенні ВГС є актуальною у зв'язку 3 можливістю розвитку окультного гепатиту С (ОГС), проблема якого широко обговорюється в науковій літературі. При цій формі ВГС РНК вірусу не визначається в сироватці крові, але виявляється в мононуклеарах периферичної крові або в гепатоцитах. Щодо виявлення антитіл до вірусу гепатиту С виокремлюють дві форми: ОГС-серонегативний (у пацієнтів із порушенням функції печінки і відсутністю антитіл та РНК у сироватці крові) та серопозитивний (з нормальними значеннями ферментів печінки, але без вірусної РНК у сироватці крові). Серопозитивний ОГС вважають вторинним, що має свідчити про очевидність факту наявності класичного варіанту ВГС в певний момент раніше. Поширеність ОГС оцінюють на рівні 2-3\% загальної популяції (Baden R. et al., 2014; Lin H. et al., 2016). Відзначимо, що детекція в мононуклеарах можлива лише у 70\% випадків, а частина, що залишилася, може бути виявлена лише під час молекулярної діагностики біоптату печінки (Carreño V., 2006). Доведена також реплікація вірусу гепатиту C в мононуклеарних лейкоцитах периферичної крові при ОГC (Castillo I. et al., 2005). Тому питання щодо здатності людей з ОГС бути джерелами інфікування для інших осіб залишається відкритим. Якщо передача ОГС статевим шляхом як мінімум малоймовірна, то значення донорів з ОГС для служби крові є, на наш погляд, вкрай актуальним питанням, тим більше, що схвалених підходів до скринінгу донорської крові на ОГС не існує.

\section{Висновки}

Епідемічний процес ВГС у Сумській області у період 19912019 рр. характеризувався певними еволюційними змінами. Загальна захворюваність на ВГС за цей період підвищилась у 25 разів, проте це відбувалося на тлі зниження активності механізму передачі вірусу і пов'язано з візуалізацією частини прихованого компонента епідемічного процесу ВГС завдяки покращенню діагностики та поліпшенню реєстрації випадків цієї інфекції.

На початку 1990-х рр. прихований компонент епідемічного процесу суттєво переважав над його маніфестною частиною: на 1 випадок маніфестного перебігу ВГС доводилося >2000 латентних випадків. Протягом наступних 18 років цей показник знизився до 1:60.

Вдосконалення діагностики і покращення реєстрації ВГС активізували протиепідемічну та профілактичну роботу серед населення, що, у свою чергу, привело до спаду активності механізму передачі збудника, насамперед за рахунок зниження частоти реалізації нозокоміального і статевого шляхів його передачі та меншою мірою - за рахунок ін'єкційного вживання наркотичних засобів, і циркуляція вірусу серед населення в цілому у період 1991-2019 рр. зменшилася у 2 рази.

При проведенні епідемічних розслідувань у 80-84\% випадків ВГС шляхи передачі залишаються невідомими. У структурі встановлених шляхів передачі переважають вживання ін'єкційних наркотичних засобів та незахищені статеві контакти.

Найбільшою мірою вірусом гепатиту С уражується населення у віковій групі 25-49 років. Діти рідко залучаються до епідемічного процесу ВГС; рівні захворюваності дитячого населення коливаються від 4,3 на 100 тис. населення до 0 з тенденцією до суттєвого зниження хронічного і помірного зниження гострого ВГС.

Захворюваність на ВГС удвічі вища серед чоловіків ніж серед жінок, що може бути пов'язано як з більшою схильністю чоловіків до ризикованого способужиття, такіз захисним ефектом естрогенів.

Визначається виражена нерівномірність розповсюдження ВГС на території Сумської області. Райони з найбільшою інтенсивністю епідемічного процесу ВГС є територіально суміжними, що вказує на схожі і, можливо, спільні умови, що підтримують активність механізму передачі інфекції на цих територіях. 


\section{Список використаної літератури}

Державна установа “Український моніторинговий та медичний центр з наркотиків та алкоголю Міністерства охорони здоров'я України" (2017) Національний звіт за 2017 рік щодо наркотичної ситуації в Україні (за даними 2016 року). Поглиблений огляд наркоситуації в Україні для Європейського моніторингового центру з наркотиків та наркотичної залежності (http:// aph.org.ua/wp-content/uploads/2017/11/National-report-2017.pdf).

Трецкая Т.А. (1993) Этиологическая структура острах вирусных гепатитов и частота выявления маркеров гепатитов А, В, С в групах високого риска инфицирования и среди населения Украины. Автореф. дис. ... канд. мед. наук. Москва, 23 с.

Шагінян В.P. (2007) Роль перинатального шляху передачі у розповсюдженні гепатитів В і C в Україні та удосконалення системи епідеміологічного нагляду. Автореф. дис. ... докт. мед. наук. Київ, 34 с.

Шагинян В.Р., Гураль А.Л., Сергеева Т.А., Мышко О.В. (2012) Вакцинация против гепатита $B$ и эпидемический процесс гепатита B Украине. Вакцинопрофилактика, 6(67): 52-58.

Baden R., Rockstroh J.K., Buti M. (2014) Natural History and Management of Hepatitis C: Does Sex Play a Role? J. Inf. Dis., 209(3): 81-85.

Carreño V. (2006) Occult hepatitis $C$ virus infection: a new form of hepatitis C. World J. Gastroenerol., 12(43): 6922-6925. Doi:10.3748/wjg.v12.i43.2000.

Castillo I., Rodríguez-Iñigo E., Bartolomé J. et al. (2005) Hepatitis C virus replicates in peripheral blood mononuclear cells of patients with occult hepatitis C virus infection. Gut, 54(5): 682-685. Doi: 10.1136/gut.2004.057281.

CDC United States (2013) Surveillance for Viral Hepatitis. Division of Vira Hepatitis and National Center for HIV/AIDS, Viral Hepatitis, STD, and TB Prevention (https://www.cdc.gov/hepatitis).

Crowley D., Murtagh R., Cullen W. (2019) Hepatitis C virus infection in Irish drug users and prisoners - a scoping review. BMC infectious diseases, 19(1): 702. Doi: $10.1186 / \mathrm{s} 12879-019-4218-6$

ECDC EU (2017) Surveillance of hepatitis B and C in the EU/EEA (https://www. slideshare.net/ECDC_EU).

Evans J.L., Hahn J.A., Page-Shafer K. et al. (2003) Gender differences in sexual and injection risk behavior among active young injection drug users in San Francisco (the UFO Study). J. Urban. Health, 80: 137-416. Doi: 10.1093/jurban/jtg 137.

Lin H., Chen X., Zhu S.P. et al. (2016) Prevalence of Occult Hepatitis C Virus Infection among Blood Donors in Jiangsu, China. Intervirol., 59: 204-210. Doi: $10.1159 / 000455854$.

Lingala S. (2015) Natural History of Hepatitis C. Gastroenterol Clin. North Am., 44(4): 717-734. Doi: 10.1016/j.gtc.2015.07.003.

Stepanova M., Younossi Z.M. (2017) Economic Burden of Hepatitis C. Infection Clin. Liver Dis., 21(3): 579-594. Doi: 10.1016/j.cld.2017.03.012.

World Health Organization (2016) Global Health Sector Strategies on Viral Hepatitis in 2016-2021 (https://www.who.int/hepatitis/strategy2016-2021/ghss-hep/en/).

World Health Organization (2017) Global Hepatitis Report 2017 (https:// apps.who.int/iris/handle/10665/255016).

Wu H.X., Wu J., Wong T. et al. (2006) Enhanced surveillance of newly acquired hepatitis C virus infection in Canada, 1998 to 2004. Scand. J. Infect. Dis. 38(6-7): 482-489. Doi: 10.1080/00365540500525161.

\section{Закономерности развития эпидемического процесса вирусного гепатита С в Сумской области}

\section{Н.А. Галушко}

Резюме. Работа посвящена изучению закономерностей развития эпидемического процесса вирусного гепатита C (ВГC) в Сумской области. В исследовании применен комплекс описательно-оценочных и аналитических приемов эпидемиологического метода иссле- дования в сочетании с методами математической статистики. Установлены динамика, интенсивность эпидемического процесса ВГС, а также ведущие пути передачи возбудителя, территории и группы повышенного риска. Предпринята попытка оценить масштабы латентного эпидемического процесса ВГС на территории Сумской области, а также объяснить причины отмечаемых тенденций динамики острого и хронического ВГС. Установлены такие эпидемиологические черты ВГС на территории Сумской области в период 1991-2019 гг.: 25-кратный рост показателей заболеваемости на фоне снижения активности механизма передачи инфекции, умеренный спад острого ВГС и одновременно умеренный рост хронической формы инфекции, 35-кратное уменьшение масштабов латентного эпидемического процесса, двукратное преобладание заболеваемости мужчин над заболеваемостью женщин, существенное снижение хронического и умеренное - острого ВГС среди детей, низкая эффективность эпидемиологических расследований случаев ВГС и существенная неравномерность территориального распределения случаев ВГС.

Ключевые слова: вирусный гепатит C, эпидемический процесс, пути передачи, группы риска.

\section{The patterns of the viral hepatitis C epidemic process in Sumy region}

\section{N.A. Galushko}

Summary. The work is devoted to the research patterns of epidemic process of viral hepatitis $\mathrm{C}(\mathrm{VHC})$ development in Sumy region in 1991-2019. A complex of descriptive, evaluative and analytical techniques of the epidemiological research method in combination with the methods of mathematical statistics are used in the study. The dynamics and intensity of the VHC epidemic process, as well as the leading routes of pathogen transmission, high-risk territories and population groups have been established. The attempt to assess the scale of the latent epidemiological process of VHC in Sumy region, as well as to explain the reasons for the observed trends in the dynamics of acute and chronic VHC was made. The following epidemiological features of VHC on the territory of the Sumy region in the period 1991-2019 were established: 25-fold increase in incidence rates against the background of a decrease in the activity of the transmission mechanism, a moderate decline in acute VHC and a simultaneous moderate increase in its chronic form, 35-fold reduction in the scale of the latent epidemiological process, two-fold prevalence of the incidence of men in comparison with the incidence of women, significant reduction in chronic and moderate reduction in acute VHC among children, low efficiency of epidemiological investigations of $\mathrm{VHC}$ cases and significant unevenness of the territorial distribution of cases of this infection.

Key words: viral hepatitis $C$, epidemic process, routes of transmission, risk groups.

Адреса для листування:

Галушко Наталія Анатоліївна 40000, Суми, вул. Римського-Корсакова, 2

Сумський державний університет, Медичний інститут,

кафедра громадського здоров'я

E-mail: galnatmed@gmail.com 